\title{
Hearing loss in Wernicke encephalopathy
}

\author{
Melissa A. Walker, MD, PhD \\ Rodrigo Zepeda, MD \\ Henrietta A. Afari, BS \\ Adam B. Cohen, MD
}

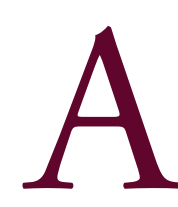

61-year-old woman presented with acute bilateral hearing loss followed by vague but acute visual disturbances, nonvertiginous dizziness, and confusion. She also reported a recent 40-pound weight loss and 1 month of persistent nausea and vomiting, all of which were attributed to diabetic gastroparesis; an extensive gastrointestinal evaluation (CT abdomen, gastric emptying study, esophagogastroduodenoscopy, and colonoscopy) was unremarkable. Medical history was notable for atrial fibrillation, diabetes mellitus, obesity, osteoarthritis, recurrent Clostridium difficile colitis, and pulmonary embolism.

On arrival, the patient had poor mental status and was only oriented to her name and the date. She perseverated and appeared anxious. She had limited bilateral ocular abduction and slight anisocoria (equal in light and dark conditions). There was end-gaze nystagmus in all directions of gaze, with prominent upbeat nystagmus in up gaze and downbeat nystagmus in down gaze (video at Neurology.org/cp). Examination also demonstrated severe bilateral hearing loss-the patient was nearly deaf and had great difficulty comprehending simple words even with shouting. Communication was only possible by writing. Otoscopic evaluation (by otolaryngology) was normal. Audiogram showed moderate sensorineural hearing loss without word recognition bilaterally (figure 1). She had mild left-sided dysmetria. Based on clinical suspicion of Wernicke encephalopathy, empiric treatment was initiated with $500 \mathrm{mg}$ of IV thiamine 3 times daily for 3 days and then $100 \mathrm{mg}$ of oral thiamine indefinitely. Serum thiamine level later returned at $35 \mathrm{nmol} / \mathrm{L}(70-180)$.

MRI brain without contrast showed abnormal T2 hyperintensity of the periaqueductal gray, quadrigeminal plate, bilateral superior colliculi, bilateral mammillary bodies, bilateral fornices, hypothalamic region, and both medial thalami with corresponding regions of restricted diffusion (figure 2).

Marked improvement of cognition, hearing, and eye movements was observed within 12 hours of treatment; cognition and hearing returned nearly to baseline after 24 hours. Ocular

\section{Practical Implications}

The diagnosis of Wernicke encephalopathy should be considered in patients presenting with hearing loss in addition to the classic features of confusion, ophthalmoparesis, nystagmus, and ataxia.

\section{Video}

Neurology.org/cp

Department of Neurology, Massachusetts General Hospital, Brigham and Women's Hospital, Harvard Medical School, Boston.

Funding information and disclosures are provided at the end of the article. Full disclosure form information provided by the authors is available with the full text of this article at Neurology.org/cp.

Correspondence to: walker.melissa@mgh.harvard.edu 
Figure 1 Audiogram results
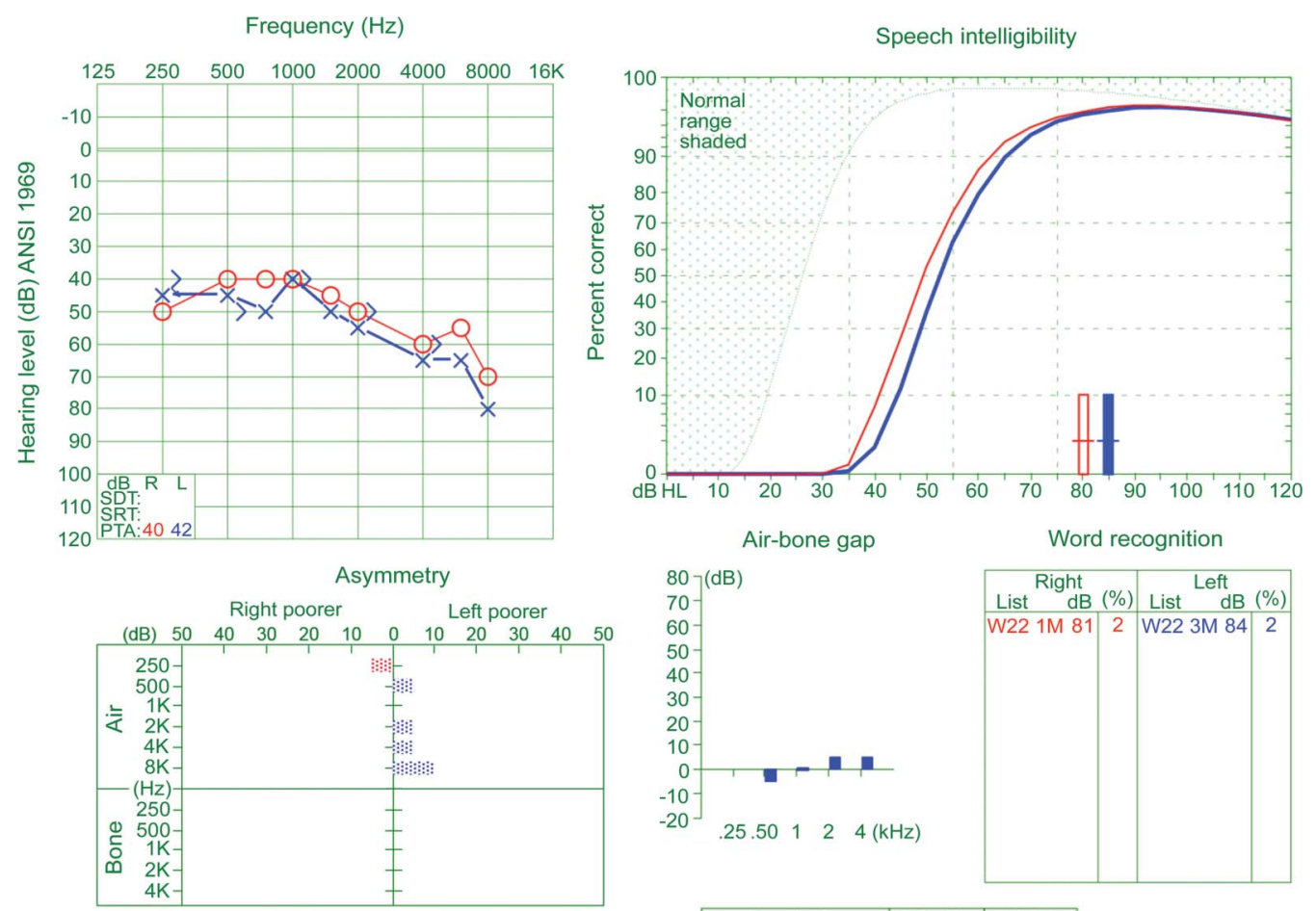

\begin{tabular}{|l|c|c|}
\multicolumn{1}{|c|}{ Tympanometry } \\
\hline Feature & Right & Left \\
\hline Volume & Normal & Normal \\
\hline Pressure & Normal & Normal \\
\hline Mobility & Normal & Stiff \\
\hline Shape & Normal & Rounded \\
\hline
\end{tabular}

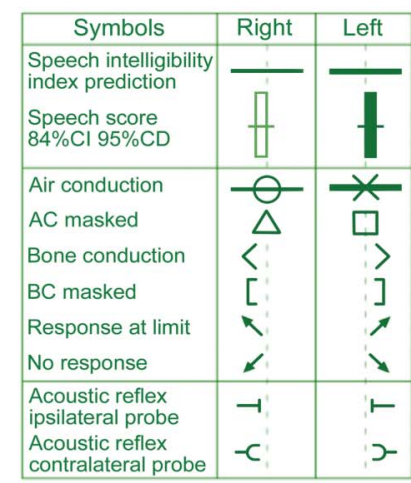

Audiogram results obtained prior to initiation of thiamine therapy were consistent with moderate sensorineural hearing loss bilaterally. Speech intelligibility was maximal at $81 \mathrm{~dB}$ in the right ear and 84 in the left with $2 \%$ whole word scoring bilaterally while pure tone average was $40 \mathrm{~dB}$ in the right and $42 \mathrm{~dB}$ in the left.

abduction was $75 \%$ restored and nystagmus had dramatically lessened in amplitude a week later. Both of these ocular signs markedly improved after a month in rehabilitation and had completely resolved 5 months after initial treatment.

\section{DISCUSSION}

A classic constellation of signs led to the diagnosis of Wernicke encephalopathy: confusion, ophthalmoparesis, nystagmus, and ataxia. The presence of encephalopathy, absence of additional brainstem signs, and the MRI findings excluded a typical vascular etiology (i.e., posterior circulation stroke).

A multiple cranial neuropathy syndrome was initially considered, but the presence of confusion, nystagmus, and ataxia steered the localization toward a multifocal parenchymal process. 
Figure 2 MRI brain
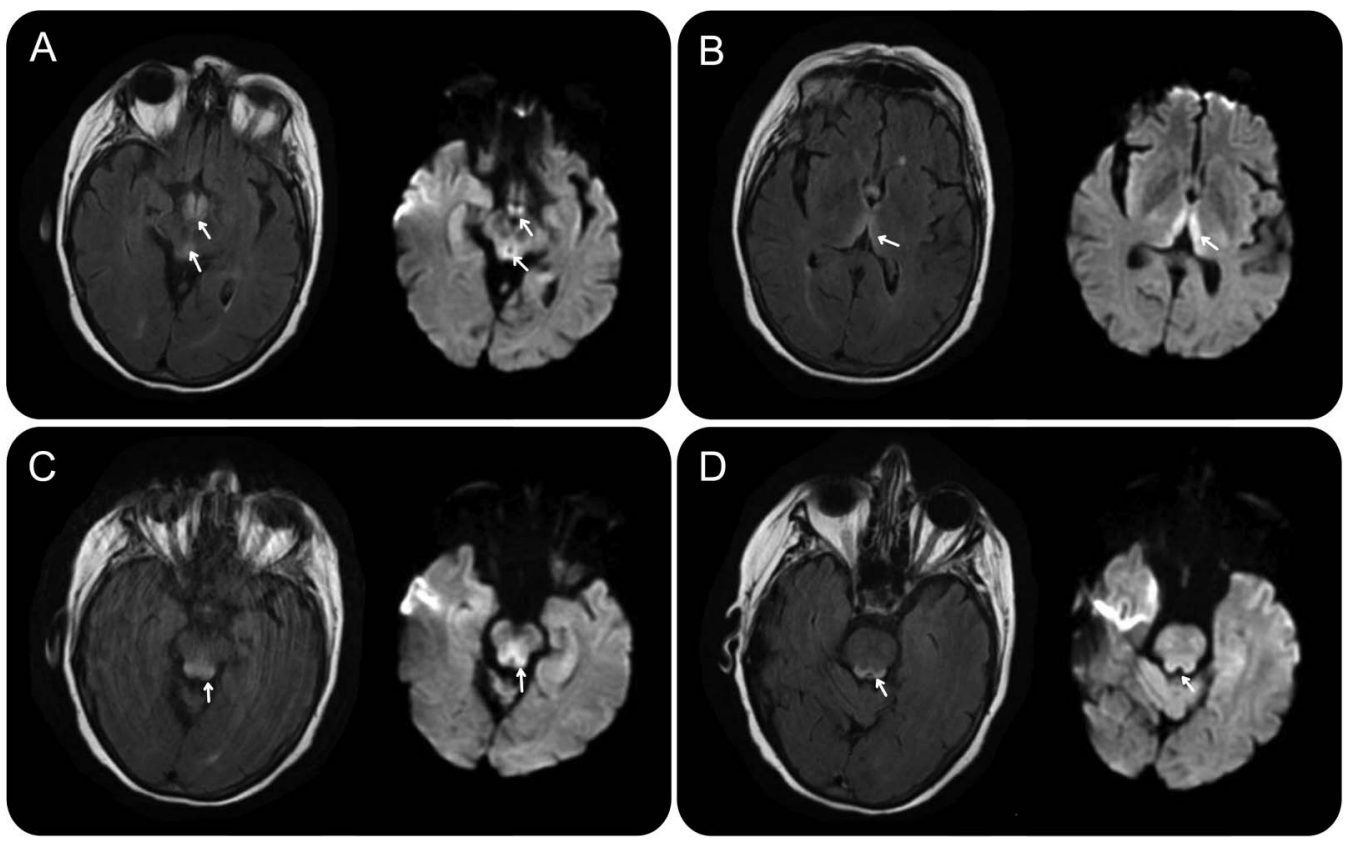

MRI brain, 4 panes: fluid-attenuated inversion recovery (left), diffusion-weighted imaging (right). Hyperintensities (left) and corresponding diffusion restriction (right) of (A) bilateral mammillary bodies and periaqueductal region, (B) bilateral medial thalami adjacent to the third ventricle, (C) midbrain tectum involving the superior colliculi and periaqueductal region, and (D) dorsal pons in the region of the fourth ventricle.

Ultimately, low serum thiamine, the MRI findings described above, ${ }^{1}$ and clinical response to thiamine repletion were confirmatory of the diagnosis.

Wernicke encephalopathy is commonly associated with nutritional deficiency secondary to alcoholism, hyperemesis gravidarum, and bariatric surgery, as well as-less frequently - to chemotherapy-induced hyperemesis, Crohn disease, and AIDS. ${ }^{2}$

The case patient posed an initial diagnostic dilemma, as she had no clear history of conditions associated with thiamine deficiency. However, she had substantial weight loss, longstanding gastrointestinal symptoms, and laboratory abnormalities suggestive of malnutrition including hypokalemia, hypomagnesemia, and elevated international normalized ratio.

Hearing loss associated with Wernicke encephalopathy is rare. A review of the English literature demonstrated 8 such cases (table), the majority of which involved bilateral hearing loss. These patients were predominantly young women (age 17-35 years) without a history of alcohol abuse. Among 7 such reported cases with associated MRI findings, 6 had abnormalities of both thalami; the sole case without thalamic involvement demonstrated MRI abnormalities of the inferior colliculi. No reported cases include audiometry. Hearing loss was responsive to thiamine treatment in most cases.

Thiamine depletion leading to Wernicke encephalopathy may also produce bilateral sensorineural hearing loss in the presence of typical MRI findings, including thalamic or inferior colliculus abnormalities. Patients with Wernicke encephalopathy unrelated to alcohol consumption-particularly young women-may be more likely to present with auditory findings, which may show marked improvement with treatment. 
Table Summary of reported cases of hearing loss with Wernicke encephalopathy

\begin{tabular}{|c|c|c|c|c|c|}
\hline Reference & $\begin{array}{l}\text { Patient } \\
\text { age, yl } \\
\text { sex }\end{array}$ & $\begin{array}{l}\text { Attributed } \\
\text { etiology of } \\
\text { thiamine } \\
\text { deficiency }\end{array}$ & $\begin{array}{l}\text { Auditory } \\
\text { symptoms }\end{array}$ & MRI T2 findings & Clinical course \\
\hline 4 & $17 / F$ & $\begin{array}{l}\text { Hyperemesis } \\
\text { gravidarum }\end{array}$ & $\begin{array}{l}\text { Bilateral } \\
\text { hearing } \\
\text { loss }\end{array}$ & $\begin{array}{l}\text { Symmetric hyperintensity of the medial thalami and } \\
\text { the posterior limbs of the internal capsule }\end{array}$ & $\begin{array}{l}\text { Hearing loss resolved } \\
\text { after treatment with IV } \\
\text { thiamine }\end{array}$ \\
\hline 5 & $31 / F$ & Crohn disease & $\begin{array}{l}\text { Bilateral } \\
\text { tinnitus }\end{array}$ & Abnormalities of the inferior colliculi & $\begin{array}{l}\text { Tinnitus resolved after } \\
48 \text { hours of IV thiamine } \\
\text { therapy }\end{array}$ \\
\hline 6 & $35 / F$ & Bariatric surgery & $\begin{array}{l}\text { Bilateral } \\
\text { hearing } \\
\text { loss }\end{array}$ & $\begin{array}{l}\text { Bilateral, symmetric hyperintensity and contrast } \\
\text { enhancement of the floor of the fourth ventricle, } \\
\text { periaqueductal gray matter, the medial portions of } \\
\text { both thalami, and the premotor and motor cortices }\end{array}$ & Not reported \\
\hline 8 & $35 / F$ & Bariatric surgery & $\begin{array}{l}\text { Bilateral } \\
\text { hearing } \\
\text { loss }\end{array}$ & $\begin{array}{l}\text { Hyperintensity of periaqueductal gray and dorsal } \\
\text { medial nucleus of thalamus }\end{array}$ & Unknown \\
\hline 9 & 23/M & $\begin{array}{l}\text { "Strictly limited } \\
\text { diet" }\end{array}$ & $\begin{array}{l}\text { Bilateral } \\
\text { hearing } \\
\text { loss }\end{array}$ & $\begin{array}{l}\text { Hyperintensity of bilateral inferior cerebellar } \\
\text { peduncles (DWI hyperintensity of the bilateral } \\
\text { inferior colliculi, posteromedial thalamus, and } \\
\text { mammillary bodies) }\end{array}$ & $\begin{array}{l}\text { Hearing loss resolved at } \\
48 \text { hours of IV thiamine } \\
\text { therapy }\end{array}$ \\
\hline 10 & 28/F & $\begin{array}{l}\text { Gastric } \\
\text { carcinoma } \\
\text { treated with } \\
\text { chemotherapy }\end{array}$ & $\begin{array}{l}\text { Bilateral } \\
\text { deafness }\end{array}$ & Not reported & $\begin{array}{l}\text { Hearing loss resolved } \\
\text { after IV thiamine therapy }\end{array}$ \\
\hline
\end{tabular}

\section{REFERENCES}

1. Zuccoli G, Pipitone N. Neuroimaging findings in acute Wernicke's encephalopathy: review of the literature. AJR Am J Roentgenol 2009;192:501-508.

2. Wilson RK, Kunci RW. Wernicke's encephalopathy: beyond alcoholism. Nat Clin Pract Neurol 2006;2:54-58.

3. Buscaglia J, Faris J. Unsteady, unfocused, and unable to hear. Am J Med 2005;18:1215-1217.

4. Flabeau O, Foubert-Samier A, Meissner W, Tison F. Hearing and seeing: unusual early signs of Wernicke encephalopathy. Neurology 2008;71:694.

5. Aasheim ET. Wernicke encephalopathy after bariatric surgery: a systematic review. Ann Surg 2008; 248:714-720.

6. Jethava A, Dasanu CA. Acute Wernicke encephalopathy and sensorineural hearing loss complicating bariatric surgery. Conn Med 2012;76:603-605.

7. Singh S, Kumar A. Wernicke encephalopathy after obesity surgery: a systematic review. Neurology 2007;68:807-811.

8. Zhang SQ, Guan YT. Acute bilateral deafness as the first symptom of Wernicke encephalopathy. AJNR Am J Neuroradiol 2012;33:E44-E45.

9. Kondo K, Fujiwara M, Murase M, et al. Severe acute metabolic acidosis and Wernicke's encephalopathy following chemotherapy with 5-fluorouracil and cisplatin: case report and review of the literature. Jpn J Clin Oncol 1996;26:234-236.

10. Kondo K, Fujiwara M, Murase M, et al. Severe acute metabolic acidosis and Wernicke's encephalopathy following chemotherapy with 5-fluorouracil and cisplatin: case report and review of the literature. Jpn J Clin Oncol 1996;26:234-236. 


\section{STUDY FUNDING}

No targeted funding reported.

\section{DISCLOSURES}

M. Walker, R. Zepeda, and H. Afari report no disclosures. A.B. Cohen receives publishing royalties from The Strokes pocketcards and Brain Hemorrhage and Trauma pocketcards (Borm Bruckmeier Publishing, 2011, 2012) and from the mobile app Resuscitation (EM Gladiators LLC, 2012) and receives research support from Center for Integration of Medicine and Innovative Technology, Boston, MA. Full disclosure form information provided by the authors is available with the full text of this article at Neurology.org/cp.

What Do You Think?

Discover what your colleagues in clinical practice are talking about. And then add to the discussion!

Neurology ${ }^{\circledR}$ Clinical Practice welcomes your feedback on our articles and seeks your practical, real-world experience on how you face opportunities and challenges in clinical practice. Correspondence regarding articles that appear in Neurology: Clinical Practice may be sent via e-mail to NCPjournal@neurology.org or by clicking on the "Respond" button in the right column of a full text version of an article. 